LITERARY KNOWLEDGE 
Also by Paisley Livingston:

Ingmar Bergman and the Rituals of Art 


\section{LITERARY KNOWLEDGE}

Humanistic Inquiry and the

Philosophy of Science

Paisley Livingston

Cornell University Press

ITHACA AND LONDON 


\section{Copyright $(\mathcal{C} \mathrm{I} 988$ by Cornell University}

All rights reserved. Except for brief quotations in a review, this book, or parts thereof, must not be reproduced in any form without permission in writing from the publisher. For information, address Cornell University Press, I 24 Roberts Place, Ithaca, New York 14850 .

First published 1988 by Cornell University Press.

International Standard Book Number 0-80 I 4-2 I IO-I (cloth)

International Standard Book Number 0-801 4-9422-2 (paper)

Library of Congress Catalog Card Number 87-4782 I

Librarians: Library of Congress cataloging information appears on the last page of the book.

The paper in this book is acid-free and meets the guidelines for permanence and durability of the Committee on Production Guidelines for Book Longevity of the Council on Library Resources. 
FOR METTE 
